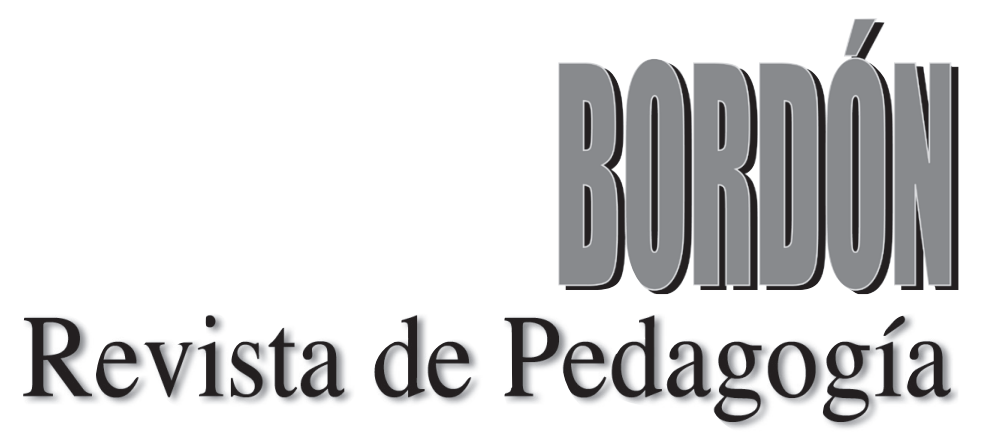

NÚMERO MONOGRÁFICO / SPECIAL ISSUE

Ética y universidad /
Ethics and university
Francisco Esteban y Pádraig Hogan
(editores invitados / guest editors)

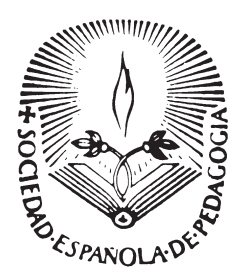

\author{
Volumen 69 \\ Número, 4 \\ 2017
}




\title{
EL CORAZÓn DEL ASUNTO: REUISARDO CUESTIONES ÉTICAS EN LA EDUCACIÓn SUPERIOR
}

\section{The heart of the matter: reviewing ethical issues in higher education}

\author{
FRANCISCO ESTEBAN ${ }^{(1)}$ Y PÁDRAIG HOGAN ${ }^{(2)}$ \\ (l) Universidad de Barcelona \\ (2) National University of Ireland Maynooth
}

D01: 10.13042/Bordon.2017.690401

El esfuerzo que las universidades están dedicando para situarse a la altura de las actuales circunstancias socioeconómicas es importante y, en consecuencia, también se está realizando un notable trabajo a la hora de formar excelentes profesionales, los mejores posibles, los más competentes, los mejor capacitados y preparados. Se podría decir que a nuestras universidades ya no se le escapa ninguna demanda que deba ser satisfecha y requiera algún tipo de atención, sea formulada por los estudiantes, por la sociedad en general o por algún ámbito profesional en concreto. Podría afirmarse, sin miedo alguno, que las universidades de hoy se han desplegado de tal manera que se ajustan a cualquier particularidad de la realidad en la que viven. Hay cosas a mejorar, dirán algunos, sí, es cierto, pero también es verdad que la acomodación que las universidades vienen desarrollando durante los últimos años es importante y relevante.

Sin embargo, y a pesar de los éxitos alcanzados, algo parece quedar desatendido, algo que, al igual que la adaptación a la realidad, también es propio de la universidad en general y de la formación universitaria en particular. Cuando hablamos de la universidad, no nos deberíamos referir solo a una institución que tenga que atender a lo que sucede a su alrededor, al mismo tiempo deberíamos pensar en una corporación de maestros y estudiantes que se dedican a buscar la verdad, el bien y la belleza de las cosas, es decir, deberíamos poder reconocernos en lo que, etimológicamente hablando, es una universitas. En otras palabras, en la universidad no solo se forman profesionales altamente cualificados, también se aspira a educar profesionales con altura ética, almas y mentes sobrias y valerosas que sepan orientar a la comunidad, personas que encarnen una vida buena, lograda y plena, en definitiva, gente que, en las calles, oficinas y hogares, impriman humanidad. Ya hace unos años, el eminente filósofo Michael Oakeshott se refería a esto con certeras palabras:

"La universidad debe cuidarse del mecenazgo de este mundo, o descubrirá que ha vendido su derecho de nacimiento por un plato de lentejas; descubrirá que, en lugar de estudiar y enseñar las lenguas y las literaturas del mundo, se transformó en una escuela de capacitación para intérpretes; que, en lugar de dedicarse a buscar hallazgos científicos, se ocupa de formar ingenieros en electrónica o químicos industriales; que, en vez de estudiar la historia, estudian y enseñan historia con un propósito ulterior; que, en vez de educar a hombres y mujeres, los capacitan exclusivamente para cubrir un nicho de la sociedad" (M. Oakeshott [2009], La voz del aprendizaje liberal. Buenos Aires: Katz Editores, pp. 143-144). 
Quizá sea el momento de concebir la formación universitaria como un acontecimiento ético, en tanto que educación personal además de profesional. Ya sabemos que los documentos oficiales, estatutos y hasta programas docentes incorporan cuestiones relativas a esa educación humanística, ética y personal, pero también creemos en aquello que dice que "del dicho al hecho hay un gran trecho", y en aquello otro de que "el papel lo aguanta todo". Ahora que estamos en época de impactos, nos atrevemos a decir que el impacto de la educación superior está muy determinado por el tipo de personas que lleguen ser los futuros profesionales y ciudadanos, y no solo por lo que sepan o no sepan hacer.

Este monográfico está conformado por artículos en español y en inglés. En relación con los primeros: los cinco trabajos que se presentan contribuyen a la recuperación de la formación ética de la que venimos hablando y que no deberíamos perder, a menos que, como dijera el cardenal Newman, queramos seguir llamando universidad a la universidad. El trabajo de los profesores Juan García, Fernando Gil y David Reyero aborda un interesante asunto, a saber: el envite de las nuevas visiones sobre la condición humana que abren las tecnologías NBIC (nanotecnologías, biotecnologías, tecnologías de la información y las ciencias cognitivas). Esa provocación se formula en varias tesis: al vaciarnos de las condiciones de humanidad, que es lo que sucede en no pocas ocasiones, pudiéramos creer que llegaremos a ser más y mejores; la descompensación existente entre posibilidades técnicas y el conocimiento de sus posibles consecuencias puede ocasionarnos serios problemas; y por último, la pretendida perfección artificial puede ocasionar que posterguemos y desterremos la importancia educativa de la vivencia particular e íntima. Aquellas personas con afán de formar a los profesionales más sofisticados no deberían dejar de leer este trabajo.

El trabajo de las profesoras Mirelle Finkler y Flávia Souza analiza la situación en la que se encuentra la formación ética en los estudios de
Odontología de una universidad brasileña. Se trata de un atractivo estudio que debería ser de interés, especialmente, para todas aquellas facultades en las que se imparten estudios vinculados al mundo de la sanidad. Sobra decir la importancia que tiene la formación ética para esos perfiles profesionales que deberán encarar dilemas éticos de manera constante, y quizá más importante, atender a personas con algún problema de salud. En dicho trabajo se apunta una conclusión que no debería pasarse por alto: la formación ética de los estudiantes pasa por la formación ética del profesorado universitario, por sus maneras de hacer y de ser. Muy relacionado con este trabajo está el de los profesores Teodor Mellen, Amelia Tey y Francisco Esteban. Aquí se analiza la formación ética en los estudios de Administración y Dirección de Empresas (ADE) de las universidades españolas. También en este ámbito se hace necesaria la formación ética, más en los tiempos que corren. Se concluye que es difícil encontrar una universidad pública o privada que no considere tal asunto. Ahora bien, cuestiones como son el tipo de planteamiento de dicha formación o su ubicación en los planes de estudios, hablan por sí solos, y se advierte que quizá a esa formación no se le otorgue toda la importancia que merece.

El trabajo de los profesores José Luis González Geraldo, Gonzalo Jover y Miquel Martínez encara el tema del Aprendizaje Servicio, quizá una de esas propuestas formativas que están más en boga en las universidades de hoy, y que están llamadas a ocupar un relevante espacio durante los años venideros. Lo más importante de este trabajo es que no se trata de una experiencia, sino de una auténtica y profunda reflexión filosófica y pedagógica sobre las potencialidades del Aprendizaje Servicio. Cualquier persona que esté trabajando en ello, o que haya pensado empezar a hacerlo, no debería dejar de acudir a este texto que, sin duda, aporta la seguridad intelectual necesaria para conducir con éxito el Aprendizaje Servicio. El trabajo de la profesora Victoria Eugenia Ángel presenta una experiencia con estudiantes de Tecnología Industrial de 
una universidad colombiana. La experiencia trata de demostrar la formación ética, humanística o personal que se puede llegar a alcanzar a través de la literatura. Se trata de un atractivo y muy sugerente trabajo, principalmente porque recupera una idea que, en muchas realidades universitarias como quizá sea la nuestra, ha quedado defenestrada. Esta es: la literatura y cualquier arte que se precie son un efectivo resorte para activar y desarrollar la formación personal y la sensibilidad ética. Aún no se sabe por qué se han borrado del mapa esos cursos, seminarios o asignaturas de tipo cultural que deberían formar parte de cualquier plan de estudios universitario, aún no se sabe por qué no instauramos en nuestras universidades una Facultad de Cultura que ilumine al resto de facultades, tal y como dijera Ortega y Gasset.

The four contributions in English to this Special Issue deal with different themes, but each shares at least one important point of departure. All four spring from a scepticism of conventional approaches to ethics in professional course in higher education, or in higher education itself more widely. Such conventional approaches - e.g. in medical courses, business courses, pedagogical courses etc. - tend to give prominence to some mastery of a range of normative ethical theories, with a view to applying such theories to practice. In recent years case studies have come to feature increasingly in such approaches, thus seeking to address a theory/practice gap that successive generations of students internationally have criticised. What the four contributing in English share are reservations about the merits of regarding ethics in higher education as a matter of learning a body of ethical theory, with a view to "applying" that theory then to practice. Such a procedure is appropriate, and often highly fruitful, in some fields of professional practice - e.g. the treatment of ulcers by doctors, the calculation of stress forces by engineers, the prediction of weather patterns by meteorological specialists. But it is quite a foreign procedure where the field in question concerns the advancement of some human good chiefly through dedicated and sustained interpersonal actions; actions that need to be carried out in highly capable, and defensible ways. Here it is helpful to call attention to a perceptive insight from Aristotle, in the opening paragraph of Book Two of his Nicomachean Ethics:

"Virtue being, as we have seen, of two kinds, intellectual and moral; intellectual virtue is produced and increased by instruction, and therefore requires experience and time; whereas moral or ethical virtue is the product of habit and has indeed derived it name (ěthos: habit), with a slight variation of form, from that word (èthos: character)" (Ethics Nic.1103a).

Aristotle is one of the most influential thinkers of Western civilisation. Yet this key insight of his has all too rarely been taken seriously. If it had been, it's difficult to see how the mastering of ethical theories, i.e. teaching about ethics, could have attained such dominance in higher education, both in professional courses and in the ethical self-understanding of university authorities. On closer inspection however, one can see how approaches that focus on "learning about" might recommend themselves over approaches that are mainly committed to the cultivation of an informed ethical capacity and an energetic ethical agency among would-be graduates. The reasons aren't difficult to understand. Firstly, the inclusion of a range of ethical theories on a course description - deontological (duty) ethics, utilitarian ethics, ethics of care, virtue ethics, consequentialist ethics - can hardly fail to give an impressive air to the course in question. This is all the more so if the course description also lists some key texts from these various schools of ethical theory. Secondly, ethical theories provide useful resources for the drawing up of codes of professional conduct for professions like medicine, business, nursing, teaching and so 
on. It should be observed however that the mining of such resources is more often than not a rather eclectic affair. That's to say it is governed less by the demands of philosophical coherence than by the more formal demand that each article of the code can do its legal job where questions of fitness to practice are concerned. Thirdly, and this is a more subtle point, the time and energy given to developing such approaches to professional ethics tend to bypass, even to obscure, the more important job of cultivating an informed ethical capacity and a robust ethical agency on the part of practitioners. This last suggestion may seem a little odd at first sight, for one might reasonably ask the question: "With such exhaustive work being undertaken on the specifying of learning outcomes for ethics courses, what could possibly remain to be done?" The answer, unfortunately, is: "virtually everything important, if ethics is to feature in higher learning as a creative force as distinct from being mainly a force for compliance and conformity."

Associating the cultivation of ethical capability with habit however can have its own obvious dangers, not the least of which is conformity of a more every day, or natural kind. For instance, one may become a "creature of habit". Accordingly, one might tend always to "do the right thing", not from a reflective sense of conviction, but because one has become thoroughly habituated in conventionallysanctioned ways of action. Aristotle has little enough to say on this, but Dewey has. In Experience and Education (1938) an elderly Dewey gathers together some of the best fruits of his educational thinking, not least on the educational importance of habit. There he writes: "The basic characteristic of habit is that every experience enacted and undergone modifies the one who acts and undergoes, while this modification affects, whether we wish it or not, the quality of subsequent experiences. For it is a somewhat different person who enters into them" ( $p .35)$. For our purposes, the crucial point here is that habit leads less to changelessness than to incremental changes
- often overlooked — that open up new possibilities for action, or that progressively close them off. If something of genuine capacitybuilding substance is attempted in the educational experiences in which students become habituated in university, then the dangers of becoming a creature of habit can yield to something more original and more promising. One might even speak of the merits making a habit of finding an original angle or approach.

These observations provide an overall perspective on the four contributions in English. The first of these is a searching philosophical paper by Paul Standish. This provides a critique of practices of "pigeonholing" questions of ethics in higher education; practices that have become dominant on campuses internationally in recent decades. The paper illustrates how such practices mark a failure to address one of the key responsibilities of a university, namely the responsibility to be that place in which values, "especially those by which a society orients itself, are questioned and tested in exemplary ways".

The second of the papers in English, by Rose Dolan and Pádraig Hogan, is a companion paper to the third paper by Anthony Malone, which follows it directly. These twin papers concentrate on the field of teacher education. This is a field where criticisms of gaps between "theory" and "practice" have been frequently voiced; where conformity with the inherited order of things has proven particularly resistant to remedies. Both papers seek to furnish some fertile ideas on the enhancement of ethical capacity among students and student teachers; both also include a strong empirical dimension, illustrating how such ideas are challenged, refined and indeed strengthened, in the often turbulent ethical circumstances of educational practice. The papers can be viewed as a twopart study - through the experience of one university - of a major reform of teacher education in Ireland. What is particularly important about these contributions is that the ideas that inspired the tenor of the reform 
sprang mainly, though not exclusively, from research activity.

The final paper by de Ruyter and Schinkel is informed by experience in the Netherlands and provides a review of four main ways in which ethics could be part of the university curriculum: (1) teaching an academic ethics module; (2) introducing students into professional ethics; (3) promoting academic citizenship; (4) fostering the ability to live a good life. The first three of these are conventional approaches by and large, and the authors are at pains to carry out an even-handed review of the merits and shortcoming of these. The later sections of the paper explore the close connection between ethics education in the university and fostering students' ability to lead a good life. The paper closes with a salutary warning about the difficulties in pursuing this goal, especially the necessity for an ethos in the university that is hospitable to this purpo se. 